\title{
ПОАИТИЧЕСКАЯ ГЕОГРАФИЯ
}

УДК 911.3:32

\section{МИНАМИКА ЭАЕКТОРААЬНЫХ ПРЕАПОЧТЕНИЙ ЖИТЕАЕЙ АГАОМЕРАЦИЙ США В 2000-2016 ГГ.}

\author{
(c) 2020 г. П.А. Рачев \\ Московский государственньий университет имени М.В Ломоносова, \\ Географический факультет, Москва, Россия \\ e-mail:prachev@geogr.msu.ru
}

\begin{abstract}
В агломерациях США проживают более $80 \%$ населения страны. Во многом именно голосования в агломерациях определяют итоги президентских или любых других выборов. Электоральные процессы, происходящие на территории компактного проживания людей, - производная их социально-экономического положения, этноконфессионального и расового состава, особенностей расселения и многих других аспектов. В последние десятилетия исследователи фиксируют процесс роста поляризации населения, тесно связанного с политическими взглядами населения. Это приводит к разобщению общества, сокращению социально-экономических взаимодействий и в перспективе к локальному изоляционизму. В настоящем исследовании проанализированы результаты президентских выборов в агломерациях США в период 2000-2016 гг. В результате анализа представлено распределение всех 382 агломераций в зависимости от результатов голосования в их границах, а также выявлены пространственные закономерности расположения этих агломераций. Исследование показало, что в рассматриваемый период население более двух третей всех агломераций имело устойчивые электоральные предпочтения. Также в исследовании на примере результатов выборов в метрополитенских ареалах представлены свидетельства продолжающегося и в отдельных случаях усиливающегося процесса «большой сортировки» и увеличения поляризации городского населения страны.
\end{abstract}

Ключевые слова: агломерации, США, электоральная география, президентские выборы, «большая сортировка», электоральные предпочтения, двухпартийная система.

DOI: $10.5922 / 1994-5280-2020-4-5$

Введение и постановка проблемы. Анализ особенностей пространственного распределения итогов выборов в Соединённых Штатах Америки (в том числе и президентских) - одна из ключевых тем исследований не только американских политических и электоральных географов, но и учёных всего мира. Этому способствует существенный массив статистических данных, собираемых в течение уже более 150 лет в пространственном масштабе от всей страны до конкретного избирательного участка.

Особенности истории формирования избирательной системы США привела к образованию двухпартийной системы [11], что обусловило разделение большей части населения страны на приверженцев Республиканской или Демократической партий. Одновременное развитие транспортных технологий и инфраструктуры в середине $\mathrm{XX}$ века (только в период президентства Д. Эйзенхауэра 1956-1960 гг. было построено $25 \%$ современных скоростных автодорог страны [20]), а также удешевление производства транспортных средств и последующая всеобщая автомобилизация (в период 19481970 гг. число автомобилей на 1000 человек в стране увеличилось почти вдвое и составило 562 шт. [10]) способствовали повышению мобильности жителей США.

В 2009 г. американские исследователи Б. Бишоп и Р. Кушинг высказали тезис о ро- 
сте концентрации населения со схожими политическими взглядами [9]. Они отследили этот процесс через исследование результатов президентских выборов в период с 1976 по 2004 г. Авторы определили, что в 1976 г. менее четверти всех американцев проживали в округах, в которых один из кандидатов в президенты одержал победу с преимуществом более чем в 20 процентных пунктов, в то время как в 2004 г. в таких округах проживало уже более половины всех имеющих право голоса [9].

Б. Бишоп и Р. Кушинг назвали это явление «Большой сортировкой» («The Big Sort») и объясняли его миграцией населения в те части страны, где проживали люди со схожими политическими взглядами. Этим миграциям способствовали и развитие инфраструктуры и автомобилизации, о которых говорилось выше.

Более $85 \%$ населения США проживают в городах [21], которые составляют только $2 \%$ территории страны. Подобное компактное расселение людей, приверженных к одной из двух политических партий, предполагает высокую вероятность возникновения социальной напряжённости внутри городских территорий и обусловливает выбор объекта исследования - население агломераций США.

Логическим завершением процесса «Большой сортировки» должно являться сбалансированное положение, при котором отсутствуют административно-территориальные или статистические единицы без явного преимущества одного из кандидатов в двухпартийной системе. При этом результаты в этих единицах должны быть устойчивыми на протяжении продолжительного промежутка времени.

В исследовании проанализированы результаты президентских выборов в агломерациях США на предмет устойчивости политических предпочтений их жителей в период 2000-2016 гг., а также динамика процесса «Большой сортировки» в этот период, то есть изменение числа округов с явным преимуществом одного из кандидатов в пределах агломераций страны.

Обзор ранее выполненных исследований. Вопросы электоральной географии США часто становились объектом исследования не только географов, но и политологов, социологов и проч. Ключевые исследования электорального ландшафта страны появляются в 1950-70-х гг. Одной из таких основополагающих работ стало исследование С. Роккана [16] о модели расколов - процесса разделения всего населения на группы в зависимости от их политических предпочтений, а также изучение причин такого разделения. Статья Роккана стала ключевой для множества последующих публикаций в этой тематике.

Важным направлением в электоральной географии США следует считать процессы выделения районов в пределах страны с устойчивыми политическими предпочтениями. Так, работа Х. Госнелла и Н. Джилла [14]одна из первых, в которых использовался инструментарий математической статистики, в частности коэффициенты корреляций. Ocновываясь на этом способе, авторы выявили пространственные закономерности в политических предпочтениях жителей Чикаго.

Среди наиболее актуальных и современных исследований с использованием математического аппарата можно выделить исследование Р. Ахмеда и М.Х. Песарана [7]. Авторы разработали регрессионную модель, объясняющую зависимость ряда социальноэкономических показателей (среди которых уровни занятости и образования населения, этнорелигиозный состав, изменение цен на жильё и др.) и показателей явки и итогов президентских выборов 2016 г. на уровне округов США друг от друга. Также на основе созданной модели авторы спрогнозировали результаты президентских выборов 2020 г, отдав незначительное преимущество кандидату от Демократической партии (от 273 до 289 голосов выборщиков). Результат кандидата от Демократической партии на выборах 2020 г. по состоянию на начало декабря (результат не является окончательным) - 306 голосов [18].

Апологетами математических методов в изучении электорального ландшафта Соединённых Штатов можно назвать К. Арчера и Ф. Шелли. В одной из своих работ [8] авторы вычислили коэффициенты корреляции между последовательными парами результатов голосований в период 1872-1984 гг,, и тем самым выяснили изменения в степени поддержки кандидатов в президенты в пределах каждого электорального цикла.

Также в исследованиях результатов выборов в США использовался и факторный анализ. Наиболее выдающейся считается работа Д. Элазара [12], в которой автор типо- 
логизировал политические культуры США. На основе социальных, культурных, этнических и религиозных особенностей населения штатов Д. Элазар выделил три типа политических культур: моралистскую, индивидуалистскую и традиционалистскую. Также автор нашёл пространственное отображение каждой из этих культур: соответственно штаты Новой Англии, среднеатлантические штаты и штаты бывших южных колоний. Помимо этого, Д. Элазар проследил процессы трансформации выделенных политических культур на всей территории страны.

Исследование Б. Бишопа и Р. Кушинга [9], которое упоминалось выше, привело к образованию научной дискуссии, и некоторые авторы критиковали научную работу, связанную с концепцией «большой сортировки». Одними из таких авторов являлись М. Фиорина и С. Абрамс [13], критика которых основывалась на том, что Б. Бишоп и Р. Кушинг не учитывают ряд факторов, влияющих на результат голосования. Среди таких факторов можно выделить минимизацию роли личности кандидатов в президенты, а личная симпатия избирателей во многом зависит от личных качеств кандидата, зачастую вне зависимости от его партийной принадлежности. Также одним из факторов М. Фиорина и С. Абрамс называли недостаточно репрезентативную выборку данных. Более конкретно, речь шла об исследовании только результатов президентских выборов и игнорировании результатов выборов губернаторов или выборов в Конгресс.

Стоит отметить, что М. Фиорина и C. Абрамс не подвергали критике саму концепцию «большой сортировки», они лишь указывали на несовершенство исследования Б. Бишопа и Р. Кушинга и предлагали возможные пути его улучшения.

Отечественные учёные также не обошли стороной вопросы электоральной географии США. Так К.Э. Аксёнов занимался вопросами неоднородности электорального ландшафта в пределах урбанизированных территорий США. В частности, в одной из своих статей автор пишет о появлении социальной поляризации в американских городах, которое сопровождалось закреплением политического противостояния «демократического» центрального города и «республиканского» пригорода $[1 ; 2]$.
Исследование П.С. Варюшина [3] затрагивает динамику изменения территориальной электоральной структуры и дифференциации электоральных предпочтений населения в период 1912-2012 гг. Одним из главных выводов работы стало то, что вследствие процессов поляризации в конце XX - начале XXI вв. начала формироваться мелкая мозаичность пространственного рисунка электорально поляризованных районов. Однако ещё более важным выводом стало то, что штаты перестают быть единой политической территориальной единицей, и основная борьба кандидатов в президенты опускается на более низкие административнотерриториальные уровни.

Можно сказать, что концепция «большой сортировки» - частный случай процесса политической поляризации. Если процесс поляризации может предполагать изменение электорального ландшафта без обязательного перемещения людей (например, вследствие изменения взглядов на какой-либо аспект политики или симпатия к определённому кандидату), то «большая сортировка» обязательно подразумевает под собой переезд в штат, округ или район со схожими политическими предпочтениями населения в его пределах.

Изучение явления с таким ярко выраженным пространственным характером - прерогатива исследователей-географов, однако в отечественной науке активно изучается политическая поляризация в целом. Так политолог П.С. Каневский через концепцию социальных размежеваний анализирует трансформацию электоральных предпочтений населения, начиная с 1980 г. [4].

Он, руководствуясь трудами С. Роккана и М. Липсета [15], говорит о формировании до 1980-х гг. «замороженной партийной системы», то есть такой системы, которая способна не менять свою структуру за счёт устойчивости электоральных предпочтений определённых социальных групп населения. «Разморозка» таких систем возможна лишь при значимых сдвигах в социально-экономических и ценностных сдвигах общества.

Помимо иллюстрации нарастания политической поляризации к 2016 г. П. Каневский показывает, что по состоянию на 2016 г. американское сообщество является идеологически более поляризованным по сравнению с рядом европейских стран. 
Политолог Н.М. Травкина рассматривает электоральную поляризацию как одну из эволюционных особенностей политической системы США [5]. В её исследовании говорится о достижении в 2016 г. высокой степени дезинтеграции политического центра страны и одновременном процессе активизации крайне левых и крайне правых сил. Одной из ключевых причин, которые привели политическую систему США в такое состояние, называется национально-этническая неоднородность среднего класса, который традиционно выступал гарантом политической стабильности американского общества [5].

Стоит отметить, что в двух представленных выше работах пространственный аспект никак не затрагивается, а концепция политической поляризации рассматривается исключительно в плоскости спектра политических взглядов разных социально-экономических и расово-этнических групп.

Однако в исследовании О.А. Фроловой политическая поляризация анализируется на уровне штатов США [6]. Наряду с анализом возможных причин изменения политических предпочтений в рамках одного электорального цикла в колеблющихся штатах автор приводит список штатов, стабильно голосующих за кандидатов от Демократической или Республиканской партий. Это, конечно, очень крупный масштаб для формулирования каких-либо выводов об электоральных предпочтениях отдельных групп населения, но работа О.А. Фроловой, безусловно, является примером рассмотрения пространственного аспекта явления в политологическом исследовании.

Таким образом, в русскоязычных публикациях рассматриваются аспекты политической поляризации прежде всего в оптике политологических, социально-экономических, расово-этнических и реже демографических различий населения безотносительно мест их проживания. Рассмотрение политической поляризации через призму пространственного отображения результатов голосований, а также динамику этого процесса (то есть процесса «большой сортировки») в разрезе городских агломераций определяет научную новизну представленной статьи.

Материалы и методика исследований. В рамках исследования рассмотрены данные об итогах президентских выборов в 382 агломерациях США в период 2000-2016 гг., взя- тые из портала Д. Лейпа «Атлас президентских выборов США» [18].

Под агломерацией в этом исследовании понимается метрополитенский статистический ареал (Metropolitan Statistical Area, MSA), который был выделен исключительно для целей переписи населения и статистического учёта. Согласно определению Административно-бюджетного управления США, которое ответственно за выделение статистических единиц в стране, метрополитенский статистический ареал - это территория, в пределах которой есть как минимум один урбанизированный ареал численностью населения не менее 50000 чел. Под урбанизированным ареалом понимается территория в пределах населённого пункта с плотностью населения свыше 1000 человек на 1 квадратную милю (около 2600 чел./км²) [19]. Метрополитенский статистический ареал (далее МСА) объединяет в своих пределах центральный округ (округа), в котором расположено ядро агломерации, а также прилегающие к нему периферийные округа с высокой степенью социальной и экономической интеграции с центральным округом, которая выражается в объёме маятниковых миграций (не менее $25 \%$ резидентов периферийного округа регулярно совершает поездки на работу в ядро агломерации) [17].

МСА США образованы совокупностью 1165 округов (counties), выделенных согласно принципам, указанным выше. По состоянию на 2016 г. совокупная численность населения в этих округах составляла $85,72 \%$, а число зарегистрированных голосов на президентских выборах в их пределах $-85,45 \%$. Все агломерации США, в рамках которых изучались электоральные предпочтения населения показаны на рисунке 1 .

Для того, чтобы отследить устойчивость электоральных предпочтений жителей агломераций США была использована одна из базовых концепций комбинаторики - дерево вариантов (или дерево решений). Дерево вариантов учитывает все возможные комбинации итогов президентских выборов в XXI в. Эта концепция позволяет также проанализировать всю совокупность элементов (в нашем случае агломераций) на предмет соответствия той или иной комбинации и в дальнейшем оценить получившееся распределение в целом и каждое отдельное множество в частности. 


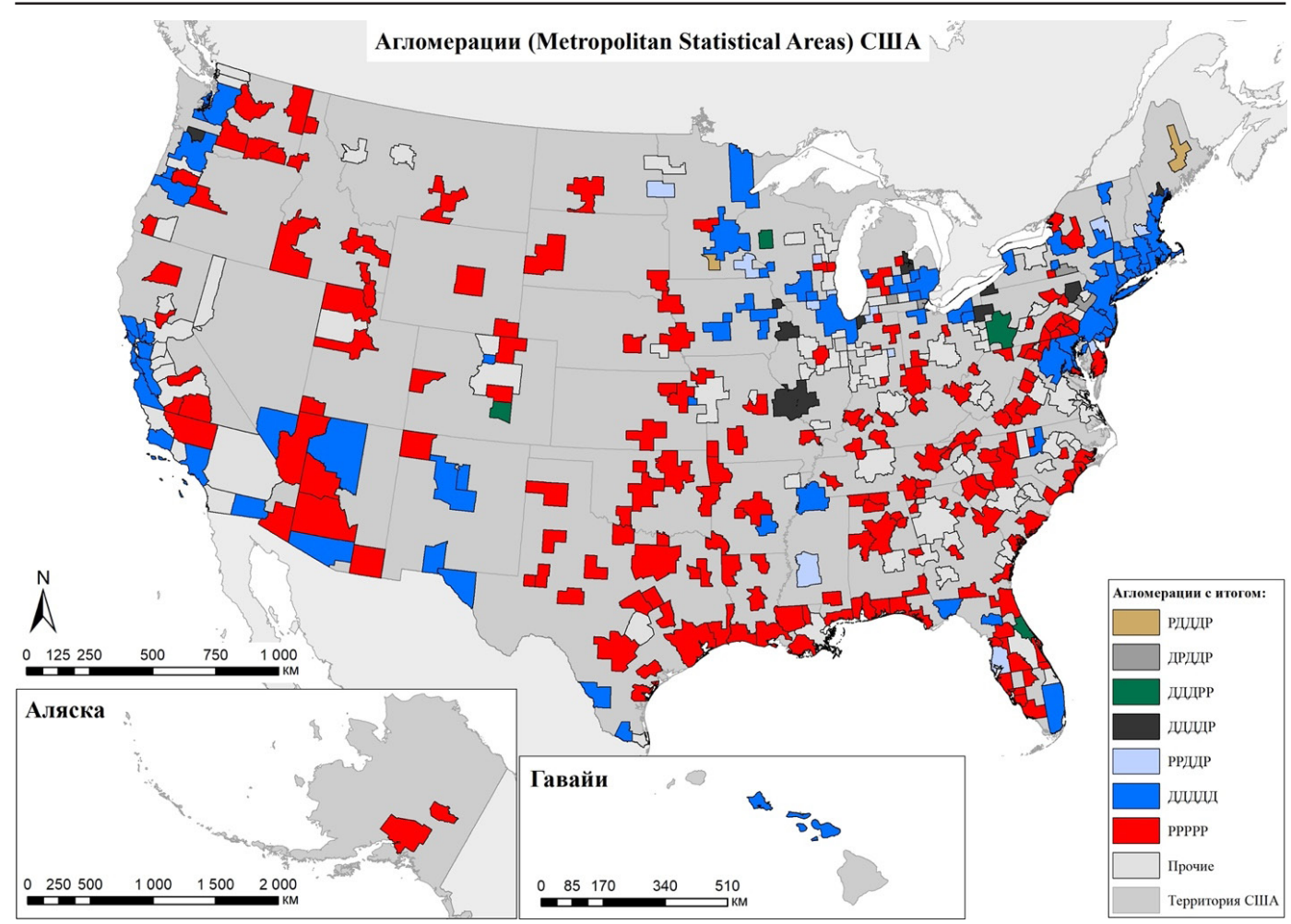

Рис. 1. Метрополитенские статистические ареалы США

Составлено автором.

Итоги 5 президентских выборов в каждой из 382 агломераций представлены в виде последовательности 5 букв в зависимости от победы кандидата от Республиканской (Р) или Демократической (Д) партий. На рисунке 2 изображено дерево вариантов итогов выборов, и оно показывает, что возможно 32 варианта результатов 5 последних президентских выборов $\left(2^{5}=32\right)$. Например, последовательность РРРРД означает, что в период 2000-2012 гг. победу в агломерации одерживал кандидат от Республиканской партии, а в 2016 г. - кандидат от Демократической партии. Всю совокупность агломераций США можно рассмотреть через 32 максимально возможных множества, которые отражают электоральное поведение, в сущности, городских жителей.

Одинаковая последовательность результатов президентских выборов в агломерациях может в первом приближении говорить о схожести взглядов проживающего в них населения, а также схожий социально-экономический, демографический и этнический профиль, однако уверенно утверждать такое было бы грубой ошибкой. В представленном исследовании рассматриваются прежде всего особенности распределения агломераций в зависимости от итогов выборов, закономерности пространственной конфигурации агломераций с одинаковой последовательностью результатов голосований в макромасштабе, а также общенациональные тренды в отношении явления «большой сортировки».

Для более детального изучения схожести результатов президентских выборов в агломерациях и явления «большой сортировки» в меньшем масштабе необходимо применять полимасштабный подход к изучению их внутренней неоднородности и анализировать результаты на уровне избирательных участков.

\section{Результаты исследований.}

Динамика процесса «больщой сортировки» в маситабе страны. Совокупная доля голосов всех агломераций в общем числе голосов в США выросла с 83,6\% в 2000 г. до $85,45 \%$ в 2016 г.

При этом анализ динамики совокупной доли голосов за республиканцев в агломерациях в общей численности голосов за кандидатов от Республиканской партии 
в стране показывает, что в пределах МСА в период 2000-2016 гг. поддержка снизилась на 0,7 п. П. (с 80,7 до 80\%). Одновременно с этим, доля голосов за представителей Демократической партии в общей доле голосов в США за аналогичный период увеличилась на 4,4 п. п. (с 86,\% до 90,5\%).

Подобная разнонаправленная динамика долей голосов в агломерациях может говорить о растущей поляризации общества и продолжении процесса «большой сортировки», выражающегося в увеличивающейся концентрации приверженцев Демократической партии в МСA.

Одновременное увеличение значимости агломераций в общем результате для Демократической партии (на 4,4 п. п. в рассматриваемый период) и незначительное уменьшение доли голосов за кандидата от Республиканской партии (на 0,7 п. п. в рассматриваемый период) говорят растущей по- ляризации и продолжении процесса «большой сортировки».

Против этого тезиса может говорить увеличение числа голосующих в агломерациях по сравнению с сельской местностью, однако доля голосов в рассматриваемый период росла значительно медленнее (см. значения выше). В агломерациях всё больше граждан голосуют за кандидата-демократа, при этом число приверженцев Республиканской партии снижается.

В качестве ещё одного доказательства продолжающегося процесса «большой сортировки» можно привести график на рисунке 3. На нём показано изменение числа агломераций, в которых один из кандидатов одержал убедительную победу (более 20 п. п. сообразно методике Б. Бишопа и Р. Кушинга [9]), а также изменение числа агломераций, в которых преимущества одного их кандидатов не наблюдается.

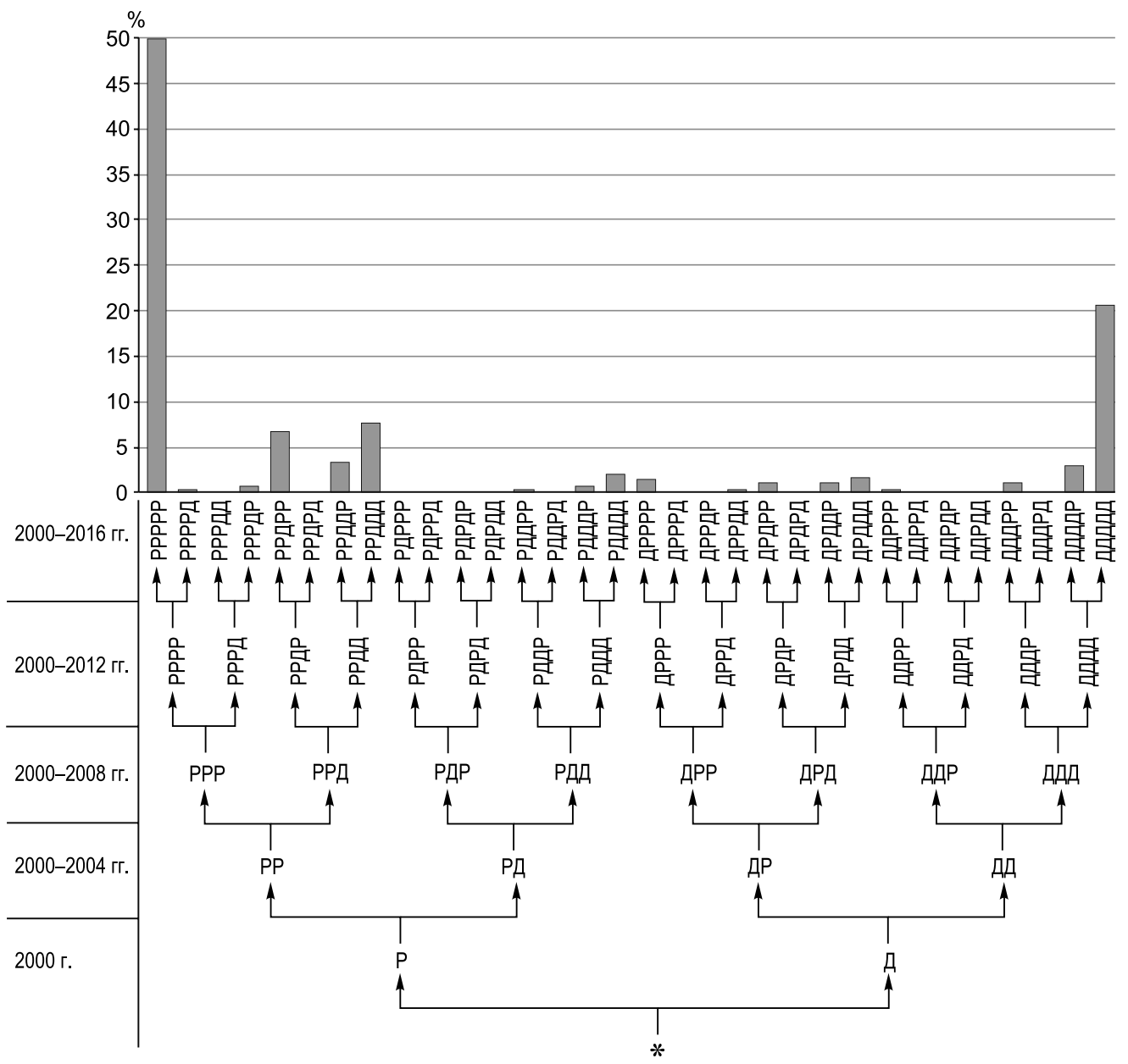

Рис. 2. Распределение агломераций США в зависимости от итогов голосования жителей на президентских выборах 2000-2016 гг.

Составлено автором. 
Одним из главных критериев процесса поляризации электорального ландшафта по Б. Бишопу и Р. Кушингу является сокращение числа административно-территориальных единиц без преимущества одного из кандидатов и одновременное увеличение округов, поддерживающего представителя одной из партий в период 1976-2004 гг. Та же самая ситуация наблюдается и в разрезе агломераций в период 2000-2016 гг.: агломераций без существенного преимущества одного из кандидатов стало меньше на 48, причём две трети из них пришлись на вторую половину периода.

Распределение МСА США в зависимости от результатов голосований. МСА категорий РРPРP и ДДДДД. На рисунке 2 можно увидеть результаты распределения агломераций по всем комбинациям дерева вариантов. Видно, что в $267 \mathrm{MCA} \mathrm{из} 382$ (или 69,7\%) наблюдаются всего 2 последовательности результатов голосования: РРРРР и ДДдДД. Таким образом, более двух третей МСА, составляющих в среднем около $61 \%$ всех голосов на президентских выборах в XXI веке, всегда в этот период в совокупности голосовали за кандидата от одной из партий, и только в оставшихся 115 агломерациях (общая численность голосов в их пределах в 2016 г. составила 33,01 млн человек или 24\% от общего числа голосов в стране) результаты голосований не были такими устойчивыми.

Однако такая существенная доля агломераций, попадающая в эти две последова-

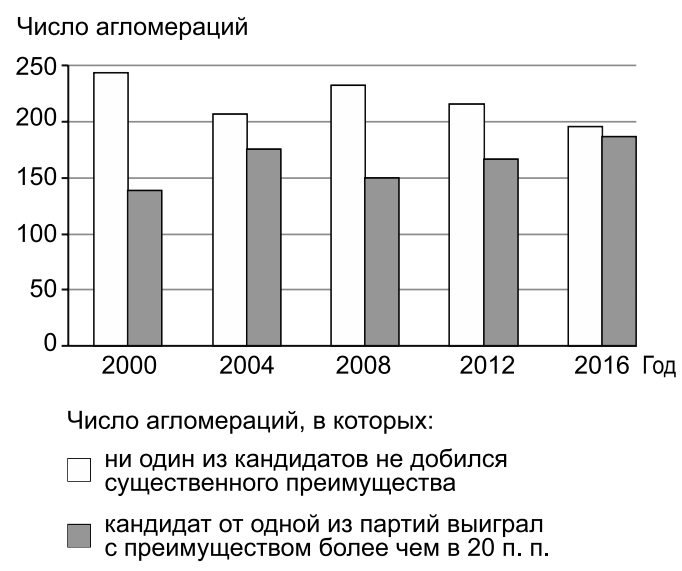

Рис. 3. Динамика числа агломераций без явного преимущества одного из кандидатов в Президенты в период 2000-2016 гг. Составлено автором. тельности, ещё не говорит о безоговорочной поддержке одного из кандидатов в этих агломерациях. Например, кандидат от Республиканской партии в 2008 г. и 2012 г. в агломерациях ДДДДД набирал в совокупности на 950 тыс. и на 450 тыс. голосов больше, чем в агломерациях РРРРР.

Таблица 1 показывает изменение основных показателей всей совокупности агломераций категорий РРРРР и ДДДДД. В 2016 г. совокупное число агломераций в этих двух категориях с явным преимуществом одного из кандидатов достигает максимума за последние 5 циклов, причём исключительно за счёт «республиканских» агломераций (в «демократических» число таких агломераций сократилось на треть). Процесс «большой сортировки» в МСА двух категорий, достигнув локального максимума по итогам выборов 2004 г., замедлился, однако к 2016 г. незначительно превзошёл его.

Продолжающаяся «большая сортировка» в этих агломерациях сопровождается двумя одновременными процессами: увеличением доли «республиканских» МСА в совокупной численности городского населения и числе проголосовавших на выборах, а также сокращением этих показателей у «демократических» МСА. Если доля голосов в агломерациях категории РРРРР в общем числе голосов увеличилась за 16 лет на 6\%, то в «демократических» агломерациях в аналогичный период совокупная доля голосов уменьшалась в течение каждого цикла и снизилась в общем на 5,4\%

Совокупная доля агломераций с наиболее устойчивыми электоральными предпочтениями на фоне параллельных движений агломераций в двух категорий незначительно уменьшилась за счёт большей численности населения в «демократических» метрополитенских ареалов (на 1,2\%).

На рисунке 4 показано, как за рассматриваемый период менялась доля голосов за кандидата от Демократической партии на президентских выборах в агломерациях, имеющих последовательность РРРРР, а также долю голосов за кандидата-республиканца в тех агломерациях, последовательность которых ДДДДД.

МСА с результатами голосования РРРРР и ДДДДД в последних 5 выборах - это оплоты Республиканской и Демократической партий, по аналогии с традиционно «республи- 
Таблица 1. Основные показатели агломераций категорий РРРРР и дДдДд в период 2000-2016 гг.

\begin{tabular}{|c|c|c|c|c|c|c|}
\hline $\begin{array}{c}\text { Категория } \\
\text { агломерации }\end{array}$ & Показатель & 2000 г. & 2004 г. & 2008 г. & 2012 г. & 2016 г. \\
\hline \multirow{4}{*}{ PPPPP } & Всего агломераций & \multicolumn{5}{|c|}{189} \\
\hline & $\begin{array}{l}\text { Доля в общей численности } \\
\text { агломераций, \% }\end{array}$ & 26,55 & 26,99 & 27,82 & 28,08 & 28,52 \\
\hline & $\begin{array}{l}\text { Доля голосов от общего } \\
\text { числа агломераций, \% }\end{array}$ & 25,46 & 25,96 & 26,33 & 26,60 & 26,99 \\
\hline & $\begin{array}{l}\text { Число агломераций } \\
\text { с явным преимуществом } \\
\text { одного из кандидатов }\end{array}$ & 109 & 135 & 90 & 113 & 138 \\
\hline \multirow{4}{*}{ дДддД } & Всего агломераций & \multicolumn{5}{|c|}{78} \\
\hline & $\begin{array}{l}\text { Доля в общей численности } \\
\text { агломераций, \% }\end{array}$ & 46,78 & 46,05 & 45,04 & 44,71 & 44,19 \\
\hline & $\begin{array}{l}\text { Доля голосов от общего } \\
\text { числа агломераций, \% }\end{array}$ & 47,24 & 46,22 & 45,49 & 45,11 & 44,84 \\
\hline & $\begin{array}{l}\text { Число агломераций с } \\
\text { явным преимуществом } \\
\text { одного из кандидатов }\end{array}$ & 27 & 30 & 55 & 48 & 36 \\
\hline \multirow{4}{*}{ Всего } & Всего агломераций & \multicolumn{5}{|c|}{267} \\
\hline & $\begin{array}{l}\text { Доля в общей численности } \\
\text { агломераций, \% }\end{array}$ & 73,33 & 73,04 & 72,86 & 72,79 & 72,71 \\
\hline & $\begin{array}{l}\text { Доля голосов от общего } \\
\text { числа агломераций, \% }\end{array}$ & 72,70 & 72,18 & 71,82 & 71,71 & 71,83 \\
\hline & $\begin{array}{l}\text { Число агломераций } \\
\text { с явным преимуществом } \\
\text { одного из кандидатов }\end{array}$ & 136 & 165 & 145 & 161 & 174 \\
\hline
\end{tabular}

Рассчитано автором.

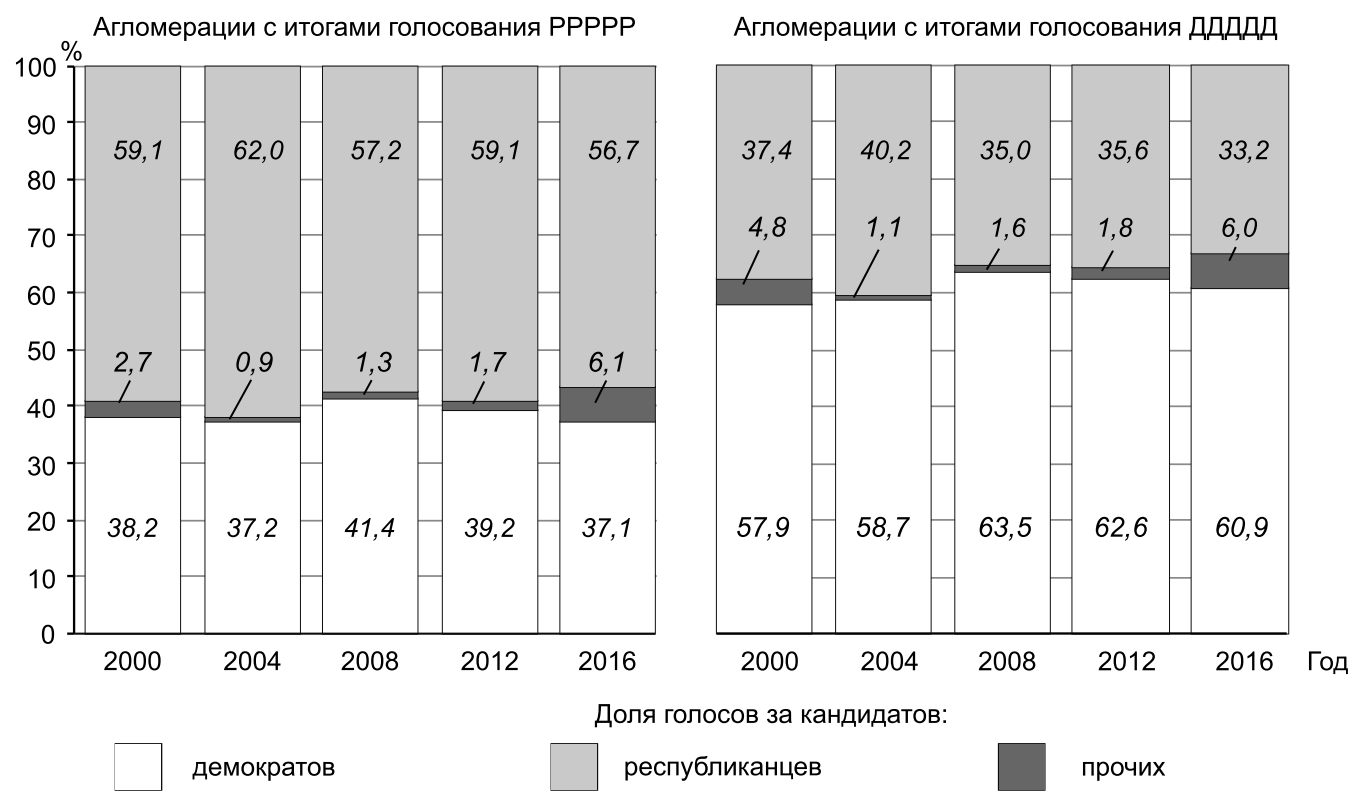

Рис. 4. Распределение голосов в агломерациях с итогами голосования РРРРР и ДДДДд в период 2000-2016 гг.

Составлено автором.

канскими» и «демократическими» штатами. Однако с 2008 г. для обеих категорий агломераций характерно снижение доли голосов как за кандидатов от Демократической, так и от Республиканской партий. Это явление связано с постепенным ростом популярности третьих кандидатов (от Либертарианской партии США) с 2008 г.: на 4,5 п. п. 
в агломерациях РРРРР и на 5,1 п. п. в агломерациях ДДДДД.

Однако, если проанализировать, какую долю от всех голосов за кандидатов от Республиканской и Демократической партий во всей стране составляют соответствующие голоса в агломерациях категории РРРРР и ДДДДД, то можно увидеть картину, изображённую на рисунке 5 .

При относительно неизменной совокупной доле голосов агломераций категорий РРРРР и ДДДДД в общем числе голосов в стране (в рассматриваемый период она увеличилась на 0,7 п. п.) наблюдается одновременный рост доли голосов за кандидата от Демократической партии и снижение доли голосов за кандидата-республиканца в агломерациях категории ДдДДД (на 1,3 п. п. и на 1,1 п. п. соответственно). В агломерациях категории РРРРР ситуация выражена не так ярко: доля голосов за кандидата-республиканца в общем числе голосов за него в стране выросла на 2,2 п. п., однако доля голосов за демократа не уменьшилась, а, хоть и незначительно, но тоже выросла на 1 п. п.

При этом доля голосов за кандидата от Республиканской партии в агломерациях других категорий, а также в сельской мест- ности растёт незначительно, в отличие от тенденций долей голосов за представителя от Демократической партии. Доля голосов в сельской местности за 16 лет сократилась почти на треть, а доля в агломерациях других категорий выросла на 9\% (или более 2 п. п.)

Из этого можно сделать вывод, что в агломерациях категории дЛлд в период 2000-2016 гг. процесс «большой сортировки» продолжается (и становится всё более выраженным с 2008 г.), а в агломерациях категории РРРРР этот процесс если и выражен, то в гораздо менее существенной степени. Если электорат Республиканской партии «сортируется» в парадигме «переезд из исключительно демократических агломераций в исключительно республиканские», то электорат Демократической партии «сортируется» в совершенно другой плоскости - «переезд из сельской местности в любую из агломераций».

Прочие категории агломераций. Как уже было сказано выше, на 30 оставшихся возможных последовательностей результатов президентских выборов приходится только 115 агломераций (или 30,3\%). Более того, из оставшихся возможных последовательностей агломерации представлены только в 16, то есть все 382 МСА имеют только

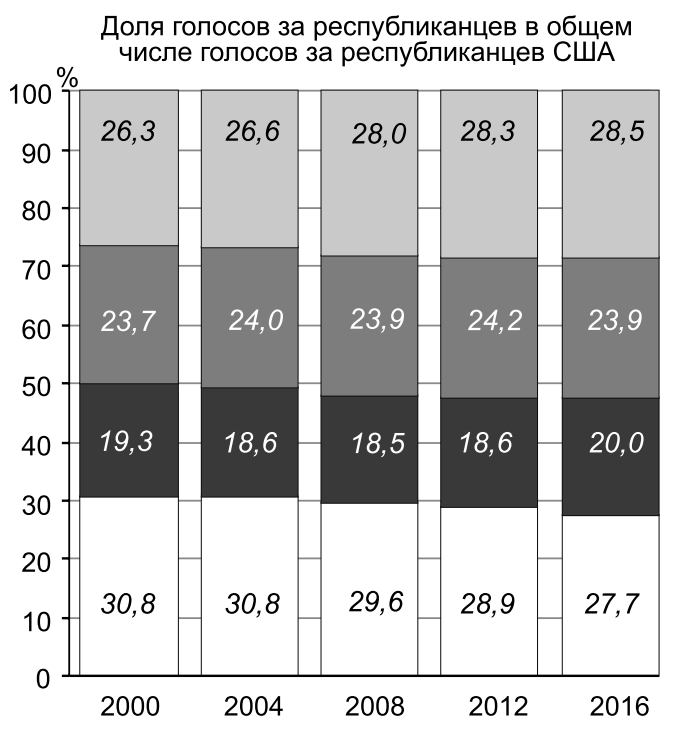

Доля голосов за демократов в общем числе голосов за демократов США

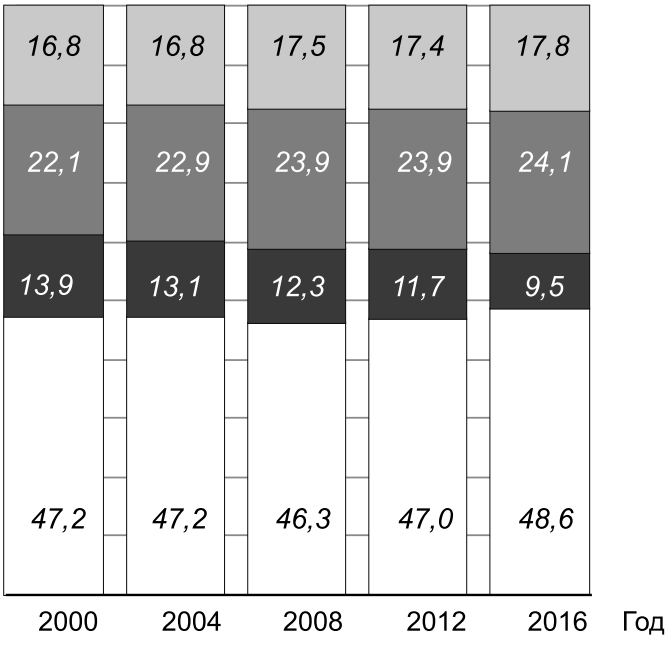

Доля голосов:

в агломерациях дДддД

в агломерациях других типов

за пределами агломераций

в агломерациях РPPPP

Рис. 5. Доли голосов за кандидатов от Республиканской и Демократической партий в агломерациях РРРРР и ДДДДД в общем числе голосов в США в период 2000-2016 гг. 
18 вариантов итогов голосований, причём только 14 из этих последовательностей представлены двумя или более агломерациями.

Всё это может говорить о чрезвычайной устойчивости политических взглядов населения МСА в США. Несмотря на то, что на посту президента в период 2000-2016 гг. 3 срока находился кандидат от Республиканской партии, а 2 срока - кандидат от Демократической партии, почти $70 \%$ всех городских территорий страны голосовали неизменно в течение этого периода.

Ниже будут рассмотрены наиболее значимые из 14 последовательностей итогов выборов. Особый интерес представляют те из них, в которых в 2016 г. победил кандидат от Республиканской партии, при этом в большинстве других периодов побеждал кандидат от Демократической, так как победу Д. Трампа в 2016 г. можно назвать сенсационной, и анализ результатов этих выборов в контексте исследования в том числе и предыдущих итогов поможет объяснить эту победу.

В первую очередь будут рассмотрены агломерации, имеющие последовательность РРДДР (см. рис. 1 и табл. 2). Особенность заключается в том, что именно такую последовательность имеют национальные результаты президентских выборов. Только 12 агломераций (3,14\% от общего числа), составляющих около 2,3\% всего городского населения имеют аналогичный результат с национальными итогами. Половина этих агломераций расположена в пределах Индустриального Приозёрья - старопромышленного и депрессивного района страны, сосредотачивающего в себе существенную долю «синих воротничков» - представителей рабочего класса. Отчасти этим объясняется победа кандидата от Республиканской партии в 2016 г. в этих МСА.

Ни в одной из агломераций этой категории за последние 5 президентских выборов преимущество одного из кандидатов не пре- вышало не только 20 п. п., но даже и 16 п. п. при совокупной численности населения, превышающей 5 млн чел. В наиболее крупной агломерации этой категории - Тампе (штат Флорида) максимальный разрыв между кандидатами за все 5 выборов не превышал 5 п. п. при средней численности голосов около 0,9-1,3 млн чел. При этом совокупная численность 11 других агломераций не превышает численности агломерации Тампы.

Двумя главными особенностями рассматриваемых ниже категорий агломераций являются победа кандидата от Республиканской партии в 2016 г., и, одновременно с этим, победа кандидата от Демократической партии, как минимум, в 3 из 4 предыдущих электоральных циклов. Только в 4 категориях, попадающих под эти условия, есть агломерации США. 21 МСА этих категорий изображены на рисунке 1 (МСА категорий РДДДР, ДРДДР, ДДДРР и ДДДДР). На карте заметна пространственная локализация агломераций этих категорий: только 5 из них не расположены в районе Индустриального Приозёрья.

Такое распределение схоже с распределением агломераций категории РРДДР, которое было рассмотрено выше. Также, все 5 этих категорий объединяет депрессивный индустриальный характер развития, обострившийся после мирового финансового кризиса 2008-2009 гг. и отчасти обусловивший победу кандидата от Республиканской партии в 2016 г., потому что кризис и его последствия полностью пришлись на период президентства кандидата от Демократической партии.

Однако если доля населения и отданных голосов в агломерациях категории РРДДР в последние 5 электоральных циклов осталось в целом неизменной, то в каждой из 4 рассматриваемых категорий МСА и во всех них в совокупности эти показатели снизились: Так почти на $12 \%$ за 16 лет снизилась доля 21 агломерации этих категорий в общем числе отданных голосов в агломерациях стра-

Таблица 2. Основные показатели агломераций категории РРДДР в период 2000-2016 гг.

\begin{tabular}{|l|c|c|c|c|c|c|}
\hline \multicolumn{1}{|c|}{ Показатель } & 2000 г. & 2004 г. & 2008 г. & 2012 г. & 2016 г. \\
\hline Всего агломераций & \multicolumn{5}{|c|}{12} \\
\hline Доля в общей численности агломераций, \% & 2,12 & 2,14 & 2,15 & 2,13 & 2,14 \\
\hline Доля голосов от общего числа агломераций, \% & 2,32 & 2,36 & 2,34 & 2,38 & 2,35 \\
\hline $\begin{array}{l}\text { Число агломераций с явным преимуществом } \\
\text { одного из кандидатов }\end{array}$ & 0 & 0 & 0 & 0 & 0 \\
\hline
\end{tabular}

Рассчитано автором. 
Таблица 3. Основные показатели агломераций категорий РДДДР, ДРДДР, ДДДРР и ДДДДР в период 2000-2016 гг.

\begin{tabular}{|c|c|c|c|c|c|c|}
\hline $\begin{array}{c}\text { Категория } \\
\text { агломерации }\end{array}$ & Показатель & 2000 г. & 2004 г. & 2008 г. & 2012 г. & 2016 г. \\
\hline \multirow[t]{4}{*}{ РДДДР } & Всего агломераций & \multicolumn{5}{|c|}{2} \\
\hline & $\begin{array}{l}\text { Доля в общей численности } \\
\text { агломераций, \% }\end{array}$ & 0,10 & 0,10 & 0,10 & 0,09 & 0,09 \\
\hline & $\begin{array}{l}\text { Доля голосов от общего числа } \\
\text { агломераций, \% }\end{array}$ & 0,13 & 0,13 & 0,12 & 0,12 & 0,11 \\
\hline & $\begin{array}{l}\text { Число агломераций с явным } \\
\text { преимуществом одного } \\
\text { из кандидатов }\end{array}$ & 0 & 0 & 0 & 0 & 0 \\
\hline \multirow[t]{4}{*}{ ДРДДР } & Всего агломераций & \multicolumn{5}{|c|}{4} \\
\hline & $\begin{array}{l}\text { Доля в общей численности } \\
\text { агломераций, \% }\end{array}$ & 0,54 & 0,53 & 0,53 & 0,51 & 0,50 \\
\hline & $\begin{array}{l}\text { Доля голосов от общего числа } \\
\text { агломераций, \% }\end{array}$ & 0,58 & 0,58 & 0,55 & 0,53 & 0,54 \\
\hline & $\begin{array}{l}\text { Число агломераций с явным } \\
\text { преимуществом одного } \\
\text { из кандидатов }\end{array}$ & 0 & 0 & 0 & 0 & 1 \\
\hline \multirow[t]{4}{*}{ ДДДРР } & Всего агломераций & \multicolumn{5}{|c|}{4} \\
\hline & $\begin{array}{l}\text { Доля в общей численности } \\
\text { агломераций, \% }\end{array}$ & 1,36 & 1,31 & 1,27 & 1,23 & 1,19 \\
\hline & $\begin{array}{l}\text { Доля голосов от общего числа } \\
\text { агломераций, \% }\end{array}$ & 1,55 & 1,55 & 1,47 & 1,44 & 1,45 \\
\hline & $\begin{array}{l}\text { Число агломераций с явным } \\
\text { преимуществом одного } \\
\text { из кандидатов }\end{array}$ & 0 & 0 & 0 & 0 & 0 \\
\hline \multirow[t]{4}{*}{ ДДДДР } & Всего агломераций & \multicolumn{5}{|c|}{11} \\
\hline & $\begin{array}{l}\text { Доля в общей численности } \\
\text { агломераций, \% }\end{array}$ & 2,14 & 2,06 & 1,99 & 1,98 & 1,91 \\
\hline & $\begin{array}{l}\text { Доля голосов от общего числа } \\
\text { агломераций, \% }\end{array}$ & 2,53 & 2,48 & 2,38 & 2,30 & 2,18 \\
\hline & $\begin{array}{l}\text { Число агломераций с явным } \\
\text { преимуществом одного } \\
\text { из кандидатов }\end{array}$ & 1 & 1 & 3 & 1 & 0 \\
\hline \multirow[t]{4}{*}{ Всего } & Всего агломераций & \multicolumn{5}{|c|}{21} \\
\hline & $\begin{array}{l}\text { Доля в общей численности } \\
\text { агломераций, \% }\end{array}$ & 4,14 & 4,00 & 3,89 & 3,81 & 3,69 \\
\hline & $\begin{array}{l}\text { Доля голосов от общего числа } \\
\text { агломераций, \% }\end{array}$ & 4,79 & 4,74 & 4,52 & 4,39 & 4,28 \\
\hline & $\begin{array}{l}\text { Число агломераций с явным } \\
\text { преимуществом одного } \\
\text { из кандидатов }\end{array}$ & 1 & 1 & 3 & 1 & 1 \\
\hline
\end{tabular}

Рассчитано автором.

ны, и на 12,2\% снизилась доля населения этих ареалов в общей численности городского населения США.

Как и для агломераций категории РРДДР для МСА рассматриваемых 4 категорий нехарактерно существенное преимущество одного из кандидатов. В двух наиболее крупных агломерациях этих категорий - Сент-Луисе и Питтсбурге, которые составляют около половины всего населения исследуемых ареалов отрыв одного кандидата от другого за 5 электоральных циклов не превышает соответственно 110 тыс. чел. (около 8 п. п.) и 90 тыс. чел. (около 7 п. п.).
Выводы. Исследование динамики электоральных предпочтений жителей агломераций США в период 2000-2016 гг., а также изучение взаимосвязи предпочтений с пространственным распределением отдельных агломераций позволили сделать ряд выводов.

Распределение агломераций по всем возможным вариантам итогов голосования в рассматриваемый период говорит, об устойчивости политических предпочтений городского населения США. Более 70\% граждан, живущих в 267 агломерациях, голосуют за представителя одной партии на протяжении 
по меньшей мере 5 электоральных циклов, а на другие 30 возможных вариантов (из которых только 16 ненулевые) приходится только 115 метрополитенских ареалов.

Исследование агломераций с устойчивыми электоральными предпочтениями граждан показало, что в них продолжается процесс увеличения степени поляризации общества: доля голосов за кандидата от Демократической партии в «демократических» MCA paстёт от выборов к выборам при одновременном сокращении доли голосов за кандидата от Республиканской партии. Схожий, но чуть менее выраженный процесс характерен и для устойчивых «республиканских» МСА.

В этих двух категориях агломераций с устойчивыми электоральными предпочтениями в рассматриваемый период наблюдаются параллельно направленные тренды: в «республиканских» МСА доля населения и доля отданных голосов растут на 2 п. П. и 1,5 п. П. соответственно, а аналогичные показатели для «демократических» агломераций снижаются соответственно на 2,5 п. П. и 2,6 п. п.

Прошедшие в ноябре 2020 г. очередные президентские выборы с научной точки зрения пока нельзя анализировать в полной мере из-за возможного пересчёта голосов. Однако на примере ряда агломераций, в которых результаты уже утверждены окончательно, можно сделать вывод о том, что выявленные тенденции устойчивости политических предпочтений сохраняются и сегодня. Так из 53 агломераций с численностью населения свыше 1 млн чел. в 2016 г. 31 принадлежала либо к категории РРРРР, либо к категории ДДДДД. По результатам выборов 2020 г. во всех этих агломерациях зафиксированы результаты, аналогичные результатам 5 предыдущих выборов. Анализ тенденций процесса «большой сортировки» в этих агломерациях требует более детальной проработки окончательных результатов выборов президента.

Исследование тех категорий агломераций, которые в 2016 г. голосовали за кандидата от Республиканской партии, а на предыдущих, как правило, за кандидата-демократа, выявляет чёткую пространственную закономерность. Большинство таких метрополитенских ареалов расположены в пределах депрессивного района Индустриального Приозёрья, существенно пострадавшего в результате мирового финансового кризиса 2008-2009 гг.
Одновременно с этим, в рассматриваемых агломерациях наблюдается существенное снижение доли населения в общей численности населения МСА и одновременное уменьшение доли голосов в общем числе голосов в агломерациях (на 12,2\% и на $12 \%$ соответственно). Такое снижение связано как с ростом численности населения в других агломерациях страны (прежде всего в южных частях страны), а также с депопуляцией в депрессивных старопромышленных городах.

Основополагающим фактором процесса «большой сортировки» и продолжающей складываться пространственной структуры агломераций с устойчивыми электоральными предпочтениями является развитая транспортная инфраструктура вообще и низкие транспортные издержки в частности. «Большая сортировка» впервые проявилась с 1970х гг. в период завершения активной фазы строительства сети межштатных автострад.

Существенно расширившаяся транспортная сеть вкупе с растущим показателем автомобилизации и постепенным снижением средней стоимости автомобиля значительно снизили транспортные издержки на переезд. Население, проживающее в районах и агломерациях с отличными от них политическими взглядами, после 1970-х гг. могли переехать в более подходящий город или район со значительно меньшими затратами.

То же самое верно не только в отношении политических предпочтений, но и в отношении неравенства в доходах. Способность домохозяйства приобретать или снимать более дорогое жильё в более престижном районе делало возможным переезд из более бедного района, а этому в свою очередь способствовали развитая дорожная сеть и дешёвые автомобили. Б. Бишоп и Р. Кушинг говорят о том, что в период 1970-2004 гг. в пределах США осуществили миграцию десятки миллионов человек [9]. Этому способствовал в том числе фактор развитой сети федеральных автострад.

Наконец, основной вывод представленного исследования заключается в том, что процесс «большой сортировки», описанный Б. Бишопом и Р. Кушингом, продолжается в разрезе агломераций. В исследуемом периоде число метрополитенских ареалов, в пределах которых ни у одного из кандидатов нет существенного преимущества, снизилось на 48, причём на- 
блюдается существенное ускорение этого процесса в последние 3 электоральных цикла. Это же подтверждается тезисом об ускорении процесса поляризации в агломерациях с устойчивыми электоральными предпочтениями.

\section{СПИСОК ЛИТЕРАТУРЫ}

1. Аксёнов К.Э. Географрия голосования на президентских выборах в метрополитенских районах США // Политическая географрия: проблемы и тенденции. Баку, 1987. С. 90-95.

2. Аксёнов К.Э., Капралов Е.Г. География голосования в городах США: опыт микро-политико-географического анализа // Политическая география и современность: региональные и прикладные аспекты. Л., 1991. С. 133-150.

3. Варюшин П.С. Территориальная электоральная структура США: динамика и фракторы формирования: дисс. ... канд. геогр. наук: 25.00.24 / МГУ им. М.В. Ломоносова. М., 2017. 250 с.

4. Каневский П.С. Социальные размежевания в американском сообществе как фактор президентской кампании 2016 года // Вестн. Моск. ун-та. Сер. 18: Социология и политология. 2017. Т. 23, № 4. C. 169-182.

5. Травкина Н.М. Президентская кампания 2016 года как отражение эволюционных особенностей политической системы США // Россия и Америка в XXI веке. 2016. № 1. DOI: 10.18254/ S207054760008379-3

6. Фролова О.А. Влияние поляризации американского общества на характер и интересы политических партий в США // Вестн. РУДН. Сер.: Политология. 2011. № 4. С. 113-121.

7. Ahmed R., Pesaran M.H. Regional heterogeneity and U.S. presidential elections / Cambridge Working Papers in Economics, University of Cambridge, 2020. [Электр. ресурc]. URL: http://www.econ.cam. ac.uk/people-files/emeritus/mhp1/wp20/AhmedPesaran_Elections-Oct-18-2020.pdf (дата обращения: 01.11.2020).

8. Archer C., Shelley F. American electoral mosaic. Washington D. C.: Resource Publications in Geography, 1996. 97 p.

9. Bishop B., Cushing R.G. The big sort: why the clustering of like-minded America is tearing US apart. N. Y.: Houghton Mifflin Harcourt, 2009. 384 p.

10. Davis S.C., Boundy R.G. Transportation energy data book: Edition 38.2. Oak Rodge, Tennessee: Oak Ridge National Laboratory, 2020. $449 \mathrm{p}$.

11. Duverger $M$. Factors in a two-party and multiparty system. Party politics and pressure groups. N. Y.: Thomas Y. Crowell, 1972. 168 p.

12. Elazar $D$. The American mosaic. Impact of space, time, and culture on American politics. Boulder: Westview Press, 1994. 352 p.

13. Fiorina M.P., Adams S.A., Pope J.C. Polarization in American public: misconceptions and misreadings // The Journal of Politics. 2008. Vol. 70, № 2. P. 556-560.

14. Gosnell H., Gill N. An analysis of the 1932 presidential vote in Chicago // American Political Science Review, 1935. Vol. 29, № 6. P. 967-984.

15. Lipset M.S., Rokkan S. Party systems and voter alignments. N. Y.; L., 1967. 554 p.

16. Rokkan S. Citizens, Elections, Parties: Approaches to the Comparative Study of the Processes of Development. New York: David McKay, 1970. 464 p.

17. 2010 Standards for delineating metropolitan and micropolitan statistical areas; Notice // Federal Register, Office of Management and Budget. [Электр. pecypc]. URL: https://www.govinfo.gov/content/pkg/ FR-2010-06-28/pdf/2010-15605.pdf (дата обращения: 01.11.2020).

18. Dave leip's atlas of U.S. presidential elections. [Электр. ресурc]. URL: https://uselectionatlas.org/ (дата обращения: 1.11.2020).

19. Ratcliffe M. A century of delineating a changing landscape: The Census Bureau's Urban and Rural Classification, 1910 to 2010. [Электр. peсурc]. URL: https://www2.census.gov/geo/pdfs/reference/ua/ Century of Defining Urban.pdf (дата обращения: 1.11.2020).

20. Weingroff $\bar{R}$.F. The greatest decade. celebrating the $50^{\text {th }}$ anniversary of the eisenhower interstate system. [Электр. ресурc]. URL: https://www.fhwa.dot.gov/infrastructure/50interstate.cfm (дата обращения: 1.11.2020)

21. World Bank Data. [Электр. ресурc]. URL: https://data.worldbank.org/indicator/SP.URB.TOTL. IN.ZS?locations=US (дата обращения: 1.11.2020).

Статья поступила в редакцию 3 декабря 2020 г.

Статья принята к публикации 29 декабря 2020 г.

\section{Об авторе}

Рачев Павел Александрович - аспирант кафедры социально-экономической географии зарубежных стран географического факультета МГУ имени М.В. Ломоносова, г. Москва.

\section{Для цитирования:}

Рачев П.А. Динамика электоральных предпочтений жителей агломераций США в 2000-

2016 гг. // Региональные исследования. 2020. № 4. С. 58-71.

DOI: $10.5922 / 1994-5280-2020-4-5$ 


\title{
US urban agglomerations electoral shifts in 2000-2016
}

\author{
P.A. Rachev \\ Lomonosov Moscow State University, Faculty of Geography, Moscow, Russia \\ e-mail:prachev@geogr.msu.ru
}

\begin{abstract}
More than $80 \%$ of US population live in metropolitan areas. Voting in agglomerations largely determines the outcome of the presidential, or any other, elections. The electoral processes inside high-density territories are a derivative of settlement peculiarities, and socio-economic status, ethnic and racial composition of people at these areas. Researchers record the increase of polarization level in recent decades. This increase closely related to the population's political preferences. Polarization can lead to the disunity of society, a reduction in socio-economic interactions and to local isolationism in the long term. This article analyzes the results of the US presidential election at the level of metropolitan areas in the period of 2000-2016 and shows the distribution of all 382 agglomerations depending on the voting results within their boundaries. It is also revealing the spatial patterns of locations of these agglomerations. The article determined that more than two-thirds of all agglomeration's population has stable electoral preferences, and also provides evidence of the ongoing and, in some cases, intensifying process of "The Big Sort" and an increase of polarization level in US urban population.
\end{abstract}

Keywords: agglomerations, USA, electoral geography, presidential elections, "The Big Sort", electoral preferences, bipartisan system.

\section{REFERENCES}

1. Aksyonov K.E. Geography of voting in presidential elections in US metropolitan areas. In: Politicheskaja geografija: problemy i tendencyi [Political geography: problems and trends]. Baku, 1987, pp. 90-95. (In Russ.).

2. Aksyonov K.E., Kapralov E.G. Geography of voting in US cities: an expeience of micro-politicalgeographical analysis. In: Politicheskaja geografija i sovremennost': regio-nal'nye i prikladnye aspekty [Political Geography and Modernity: Regional and Applied Aspects]. Leningrad, 1991, pp. 133-150. (In Russ.)

3. Varyushin P.S. Territorial'naja elektoral'naja struktura SShA: dinamika i faktory formirovanija [Territorial electoral structure of the United States: dynamics and factors of formation]. PhD thesis in Geography, Moscow, 2017, 250 p. (In Russ.)

4. Kanevskiy P.S. Social cleavages in the American society as a factor of 2016 presidential campaign. Vestnik Moskovskogo universiteta. Seriya 18: Sociologiya i politologiya, 2017, vol. 23, no. 4, pp. 169181. (In Russ.)

5. Travkina N.M. Evolutionary features of the US political system and the presidential elections 2016. Rossija i Amerika v XXI veke, 2016, no. 1. DOI: 10.18254/S207054760008379-3. (In Russ.).

6. Frolova O.A. The influence of polarization of american society on nature and interests of political parties of the USA. Vestnik RUDN. Seriya: Politologiya, 2011, no. 4, pp. 113-121. (In Russ.).

7. Ahmed R., Pesaran M.H. Regional heterogeneity and US presidential elections. Cambridge Working Papers in Economics, University of Cambridge Publ., 2020. URL: http://www.econ.cam.ac.uk/peoplefiles/emeritus/mhp1/wp20/AhmedPesaran_Elections-Oct-18-2020.pdf [Accessed 01.11.2020]

8. Archer C., Shelley F. American electoral mosaic. Washington D. C.: Resource Publications in Geography, 1996. 97 p.

9. Bishop B., Cushing R.G. The big sort: Why the clustering of like-minded America is tearing US apart. New York: Houghton Mifflin Harcourt Publ., 2009. 384 p.

10. Davis S.C., Boundy R.G. Transportation energy Data Book: Edition 38.2. Oak Rodge, Tennessee: Oak Ridge National Laboratory, 2020. 449 p.

11. Duverger M. Factors in a two-party and multiparty system. Party politics and pressure groups. New York: Thomas Y. Crowell Publ., 1972. 168 p.

12. Elazar D. The American mosaic. Impact of space, time, and culture on American politics. Boulder: Westview Press, 1994. 352 p.

13. Fiorina M.P., Adams S.A., Pope J.C. Polarization in American public: misconceptions and misreadings. The Journal of Politics, 2008 , vol. 70 , no. 2, pp. 556-560.

14. Gosnell H., Gill N. An analysis of the 1932 presidential vote in Chicago. American Political Science Review, 1935, vol. 29, no 6, pp. 967-984.

15. Lipset M.S., Rokkan S. Party systems and voter alignments. New York; L., 1967. 554 p.

16. Rokkan S. Citizens, elections, parties: approaches to the comparative study of the processes of development. New York: David McKay Publ., 1970. 464 p.

17. 2010 Standards for delineating metropolitan and micropolitan statistical areas. Notice. Federal Register, Office of Management and Budget. URL: https://www.govinfo.gov/content/pkg/FR-2010-0628/pdf/2010-15605.pdf [Accessed 01.11.2020].

18. Dave Leip's Atlas of US Presidential Elections. URL: https://uselectionatlas.org/ [Accessed 01.11.2020].

19. Ratcliffe M.A Century of Delineating a Changing Landscape: The Census Bureau's Urban and Rural Classification, 1910 to 2010. URL: https://www2.census.gov/geo/pdfs/reference/ua/Century_of_ Defining_Urban.pdf [Accessed 01.11.2020].

20. Weingroff R.F. The Greatest Decade. Celebrating the $50^{\text {th }}$ Anniversary of the Eisenhower Interstate System. URL: https://www.fhwa.dot.gov/infrastructure/50interstate.cfm [Accessed 01.11.2020].

21. World Bank Data. URL: https://data.worldbank.org/indicator/SP.URB.TOTL.IN.ZS?locations=US [Accessed 01.11.2020]

Received 03.12.2020

Accepted 29.12.2020 